\title{
Geospatial Analysis of Flood Risk and Vulnerability Assessment along River Benue Basin of Kogi State
}

\author{
Emmanuel T. Umaru' ${ }^{1}$, Adeniyi Adedokun ${ }^{2}$ \\ ${ }^{1}$ Department of Urban and Regional Planning, Federal University of Technology, Minna, Niger State, Nigeria \\ ${ }^{2}$ Centre for Disaster Risk Management and Development Studies CDRM \& DS, Federal University of Technology, Minna, \\ Niger State, Nigeria \\ Email: eumaru@futminna.edu.ng
}

How to cite this paper: Umaru, E.T. and Adedokun, A. (2020) Geospatial Analysis of Flood Risk and Vulnerability Assessment along River Benue Basin of Kogi State. Journal of Geographic Information System, 12, 1-14.

https://doi.org/10.4236/jgis.2020.121001

Received: October 4, 2019

Accepted: January 14, 2020

Published: January 17, 2020

Copyright $\odot 2020$ by author(s) and Scientific Research Publishing Inc. This work is licensed under the Creative Commons Attribution International License (CC BY 4.0).

http://creativecommons.org/licenses/by/4.0/

\begin{abstract}
River flooding has become a widely distributed and devastating natural disaster that has caused significant damages both economically and socially in $\mathrm{Ni}$ geria. Although, the Nigeria Meteorological Agency (NiMet) are always on time to provide flood warnings prior to flood disasters, spatial information pertaining to the areal extent vulnerable to the hazard are not usually made available. This study focuses on the application of geospatial techniques and quantitative research method for the assessment and analysis of flood risk and vulnerability assessment along the River Benue Basin of Kogi State. Digital Elevation Model (DEM) and Landsat Thematic Mapper (TM) images for 2010, 2014 and 2018 were used. These images were processed, digitized, interpolated, classified, overlaid and buffered using the ArcMap 10.3.1 GIS software to generate classified land use/cover maps, topographic map and flood physical vulnerability maps. Household questionnaires which contained structured questions were distributed and obtained to analyse the social-economic vulnerability of the study area using descriptive analysis. The study revealed that areas within 6-kilometre buffer from the River Benue are most vulnerable to flood hazard with the vulnerability decreasing towards the southern part. The two urban areas in the study area (Abejukolo and Oguma) are vulnerable to flood threat. Abejukolo is vulnerable due to high water footprint in the town and its surroundings. The factors that increase flood vulnerability of the inhabitants are low elevation, high illiteracy rate, high numbers of dependent population, poverty, low quality housing, poor land use and planning, inadequacy or absence of risk communication tools. The study recommends the development of guidelines for land use, continuous vulnerability mapping of the study area especially in the flood risk probability months (April to Oc-
\end{abstract}


tober), construction of dams to contain release water from the upstream, collaboration of NEMA with the local Government and traditional rulers for effective risk communication and relocation of communities lying on the river Benue basin in other to reduce the population vulnerability to flood impacts.

\section{Keywords}

Geospatial, Vulnerability, Flood, Disaster

\section{Introduction}

The National Oceanic and Atmospheric Administration [1] described flood as a discharge of water more than the carrying capacity of the available channel. It is a natural disaster which has considerable consequences on human life and the neighbouring environment. Flooding has claimed several lives, forced millions of people to flee their habitual homes, and caused serious ruins of assets and downgrading of many farmlands, wetlands, forest and other natural resources of the environment worldwide. According to [2], flood disaster is regarded as the most common disaster in the world and evenly spread worldwide. In Nigeria, flooding has led to considerable socioeconomic wreck than any other natural disaster. Several literatures have shown that these three types of flood are the common flood disasters that have taken place in the Nigeria in years past. Among the highlighted flood types, river flooding is the most huge and usually most damaging. River flooding is notably extensive with regard to its drainage area, unlike coastal and urban flooding. For example, the major rivers in Nigeria (Niger and Benue) emerge by many urban areas. According to [3], river flooding takes place in the floodplains of the great rivers. The effects of global warming and unregulated human activities contribute a great deal to this occurrence. Flood disaster is intensifying and quickly turning to an annual occurrence in Nigeria especially in the coastal regions while the dry northern regions of the country are not excluded too. According to a report by the Nigerian Hydrological Service Agency [4], devastating flood disasters have occurred in the last 5 years in more than 15 states of Nigeria. The state includes Lagos, Oyo, Rivers, Niger, Kwara, Benue, Edo, Anambra, Ondo, Borno, Kogi, Osun, Delta, Sokoto, Ogun, Oyo, and Ekiti among others. It was also recorded that these flooding occur mostly between the month of July and October when excessive rainfall is experienced in the country. However, many of these flooding were linked to dam release/failure or other disequilibrium effects on the river channels such as tidal waves. Flooding has led to severe loss of lives, and properties along the river Niger and Benue basin. Many communities along the basin are constantly relocating and each time they relocate, they usually relocate to another flood risk zone which often leads them to another loss. Nigeria as a country has paid less attention to this risk. The approach to flood management requires a change of paradigm. In other to effec- 
tively manage future flood disaster worries in flood prone areas of the federation, there is need for the National Emergency Management Agency (NEMA) in collaboration with other disaster management stakeholders to be able to forecast, predict and relocate people who at the risk of flood disaster to safe location before flooding. To achieve this, it is important to embrace a competent model with geo-visualization proficiency to investigate, model and create figures for accurate and effectual judgement. Such task can be achieved through the use of geospatial technology. Geospatial technology involves the synthesis of Geographical Information System (GIS) and remote sensing (RS) methods. It is designed in a way that allows wide varieties of data to be inserted, manoeuvred, examined, scrutinised, and presented as information attributed to the earth. Moreover, [5] [6] [7] all affirmed that the use of information gotten remotely in GIS system has proven to be the best approach for evaluating river flooding and risk determination.

The paper aims at examining the area at flood risk while also determining the factors that increase the vulnerability of communities at flood risk.

\section{The Study Area}

The study area covers the river Benue basin in Kogi State, as shown in Figure 1. The areas covered are Bassa and Omala Local Government Area. Bassa Local Government is located between latitude $7^{\circ} 54^{\prime} \mathrm{N}$ and $7.90^{\circ} \mathrm{N}$ and longitude $7^{\circ} 03^{\prime} \mathrm{E}$ and $7.05^{\circ} \mathrm{E}$ while Omala Local Government is located between latitude $7^{\circ} 49^{\prime} \mathrm{N}$ and $7.817^{\circ} \mathrm{N}$ and longitude $7^{\circ} 31^{\prime} \mathrm{E}$ and $7.517^{\circ} \mathrm{E}$. The two local governments are located in the eastern part of Kogi State and traversed by the River Benue. According to the 2006 census figure by NPC, the population figures of Bassa and Omala LGA are 139,993 and 108,402 respectively with area coverage of $1925 \mathrm{~km}^{2}$

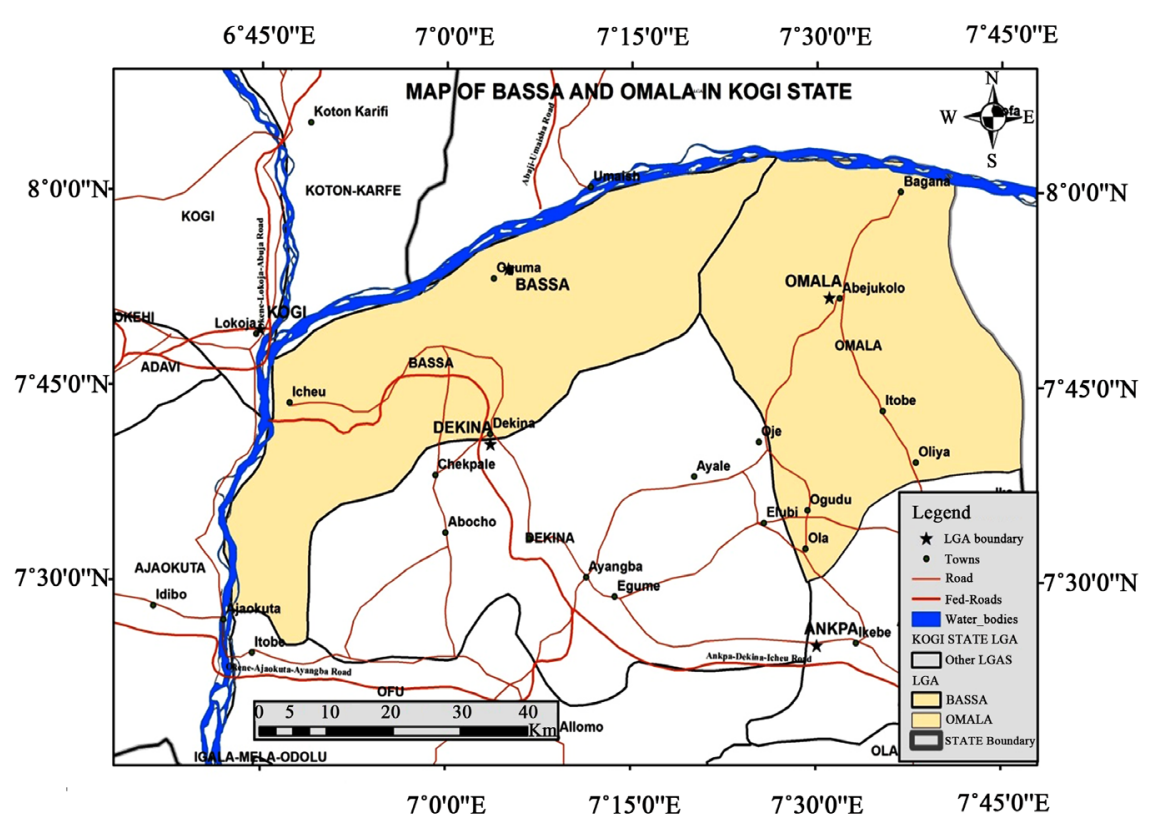

Figure 1. Map of the study area. 
and $1667 \mathrm{~km}^{2}$ respectively at the 2006 census. Annual rainfall in the study area is constantly high, with the yearly mean usually between $1100 \mathrm{~mm}$ and $1300 \mathrm{~mm}$ [8]. The temperature is seasonal, relatively high and ranges between $22^{\circ} \mathrm{C}$ and $32^{\circ} \mathrm{C}$, having February through to March as the months with highest temperature [3]. Bassa and Omala Local Government Area are inhabited by different tribes. The Igallas and Nupes are the dominant tribe in the two local governments' area. The two local governments area has about 100 settlements which includes populated towns such as Oguma, Abejikolo, Ife, Ogodu, Akishamishi, Echeu, Akakana, Akabasisi, Odeyyi, Bagana, Gboloko and Ozonogulo. The villages and settlements are mostly lineal; people live according to clans thereby giving way to the circular style.

Their major occupation includes agricultural practices, civil servant, trading and agrarian peasantry. The presence of sedimentary rocks and alluvium along the riverbeds, encourage fishing and farming. Each family produces different crops to meet their needs by farming at different altitudes of sierra. Notable among the farm produce in Kogi state include cassava, maize, coffee, cocoa, palm oil, cashews, groundnuts, yam, rice and melon. In their highlands, rearing of cattle is common among the people. Notable drainage features in the study area are Egeneja Warm Spring at Bassa Local Government Area and the Mimi River. Most towns and villages in the study area lack adequate water channel system as a result the low-lying nature and geology which results in water-logging in several areas.

\section{Data and Research Methodology}

The data used for this study was gotten from both primary and secondary sources. Primary data was collected through questionnaires, interviews and Geographic Positioning System (GPS) receiver in other to obtain coordinates of flood prone communities in the study area. Secondary data includes satellite imageries, topography maps and population data.

The questionnaire was aimed at assessing the socio economic vulnerability of some selected communities in the study area to flooding while The geographical information system (GIS) shape files gotten from digitized satellite imageries is aimed at determining areas at flood risk and assessing physical vulnerability of the areas to flood.

Images acquired from Landsat 8 on October 2010 (before 2012 flood event), October 2012 (during flood event) and 2015 (after flood event) were classified in order to assess the land cover change using ArcMap 10.3.1. Land use/cover change obtained from the classification of 2010, 2014 and 2018 images was processed and analysed within ArcMap 10.3.1 environment. A false colour composite of all the satellite imageries was created to distinct land use/cover which includes bare soil, vegetation, water bodies and built areas. With the use of Maximum Likelihood method, supervised image classification was conducted to obtain distinct land use and land cover of the terrain before and after flood. Digital Elevation 
Model was processed and classified within ArcMap 10.3.1 environment to obtain the elevation map of the area under study. Spatial data, which include land use/cover, elevation, river networks and channels retrieved in raster format, was vectorised using ArcGIS 10.3.1 sofware. Analytical operations which include data layers coordinate systems projection was carried out to integrate these data from different sources.

\subsection{Fieldwork and Primary Data Collection}

The field work was carried out to validate the flood extent as captured by the satellite imageries and to identify other areas inundated by the flood. GPS receivers and printed copies of satellite imageries were used as the field tools to delineate inundated areas.

A survey of some selected communities in the study area was carried out during the field work and basic data on the socio-economic indices such as age, sex, literacy rate, employment status, etc. Were obtained using questionnaire and compiled.

\subsection{Spatial Analysis Techniques}

Spatial analyses of the study area carried out include buffer analysis and classification of terrain elevation. Vectorised river Benue basin including its tributaries was buffered. 20-kilometre buffer distance was marked on the Kogi state part of the Benue basin. Progressively, a 6-kilometre, 13-kilometre and 20-kilometre buffer distances were identified on the Kogi state part of the Benue basin. Terrain elevation was classified into two categories of 0 - 30 meters and $30-545$ meters to represent low and high respectively.

\subsection{Hazard Zoning}

This different buffered layer was overlaid on the vectorised topographic strata using the ArcGis 10.3.1 software. The spatial intersect and erase overlay techniques was used to extract the potential flood risk areas from the overlaid buffered river basin and topographic map. The flood prone areas were classified with respect to magnitude based on elevation and distance from the river channels and water footprints in the study area. The study area was categorized into zones (high hazard, medium hazard, low hazard, and no hazard zones).

\subsection{Assessment of Socio-Economic Vulnerability}

Primary data gotten through household questionnaire deployed to some selected communities in the study area constitute the baseline data for this analysis. 364 households were sampled. Variables extracted from the baseline data were divided into demographic, socioeconomic and early warning system variables. These variables include age (Children and elderly population), gender (male and female), literacy rate, income rate, housing types, early warning systems forecast, gadgets and information dissemination. 


\section{Results and Analysis}

\subsection{Change in Land Use/Cover for 2010, 2014 and 2018}

Figures 2(a)-(c) present the land-use/cover data for the year 2010, 2014 and 2018 respectively. The land use/cover classification comprises of four categories: soil or rock, vegetation, water bodies and built-up areas.

Table 1 showed the changes that have occurred on land use and land cover in the study area between 2010, 2014 and 2018. The rate of increase/decrease between 2010 and 2014 on soil/rock, vegetation, water bodies, and built-up areas were $-5.9 \%, 1.1 \%, 6.1 \%$, and $0.9 \%$ respectively. The highest positive change took place on water bodies, while the highest negative change took place on soil/rock in 2010/2014. This change could be attributed to the release of water from the Ladgo dam in Cameroon in 2012 which flooded the study area.

The rate of increase/decrease between 2014 and 2018 on soil/rock, vegetation, water bodies, and built-up areas were $8.3 \%,-8.3 \%,-8.0 \%$, and $8.2 \%$ respectively while 2010 to 2018 increases were $2.4 \%,-9.4 \%,-1.9 \%$, and $9.1 \%$ respectively. Thus, the highest positive change occurred on soil/rock and built-up areas while the highest negative change occurred on vegetation and water bodies in 2014/2018 as in 2010/2018. The positive changes can be attributed to overgrazing, increase in farming practices and rise in demand for shelter due to increasing human population. The negative changes could be attributed mainly to increasing deforestation, increase in drought event as a result of climate change effect, and intensified use of wetland for agriculture purposes.

Consequently, the increase in soil/rock, built-up areas, and decrease in vegetation due to population increase, economic activities, use of trees as fuel, logging coupled with low elevation can increase the vulnerability of households in the Benue basin to flood hazard.

\subsection{Elevation of the Study Area}

Figure 3 presents the elevation of the study area. Elevation order was obtained by classification of the DEMs and interpolation on base map of the study area. The figure shows that, the south eastern communities including Ojaji, Oliya, and Ebeje, are located within the high-elevated land. Naturally, low slope and low elevation are areas along the river basin watershed such as Oguma, Mozu, Ogba,

Table 1. Summary of land use and Land cover (in Hectares) for the study area in 2010, 2014 and 2018.

\begin{tabular}{ccccccc}
\hline LULC Class & 2010 & 2012 & 2018 & $\begin{array}{c}\text { \% Change } \\
\text { 2010-2014 }\end{array}$ & $\begin{array}{c}\text { \% Change } \\
\text { 2014-2018 }\end{array}$ & $\begin{array}{c}\text { \% Change } \\
\mathbf{2 0 1 0 - 2 0 1 8}\end{array}$ \\
\hline Soil/rock & 0.201 & 0.160 & 0.235 & -5.9 & 8.3 & 2.4 \\
Vegetation & 0.595 & 0.623 & 0.548 & 1.1 & -8.3 & -9.4 \\
Water body & 0.048 & 0.106 & 0.033 & 6.1 & -8.0 & -1.9 \\
Built-up & 0.006 & 0.015 & 0.088 & 0.9 & 8.2 & 9.1
\end{tabular}

Source: Author's analysis, 2019. 


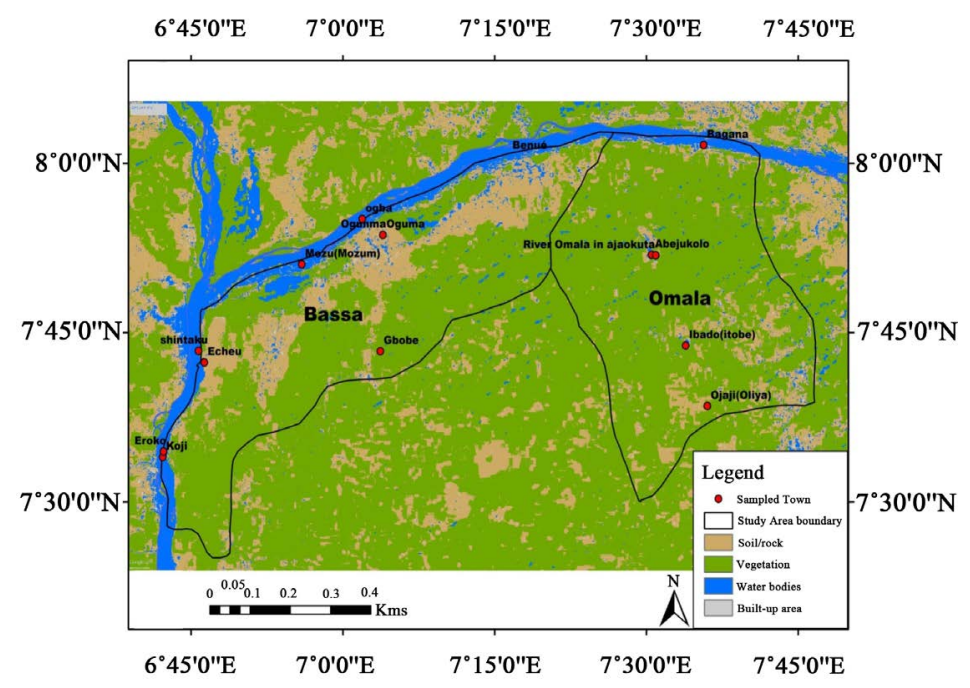

(a)

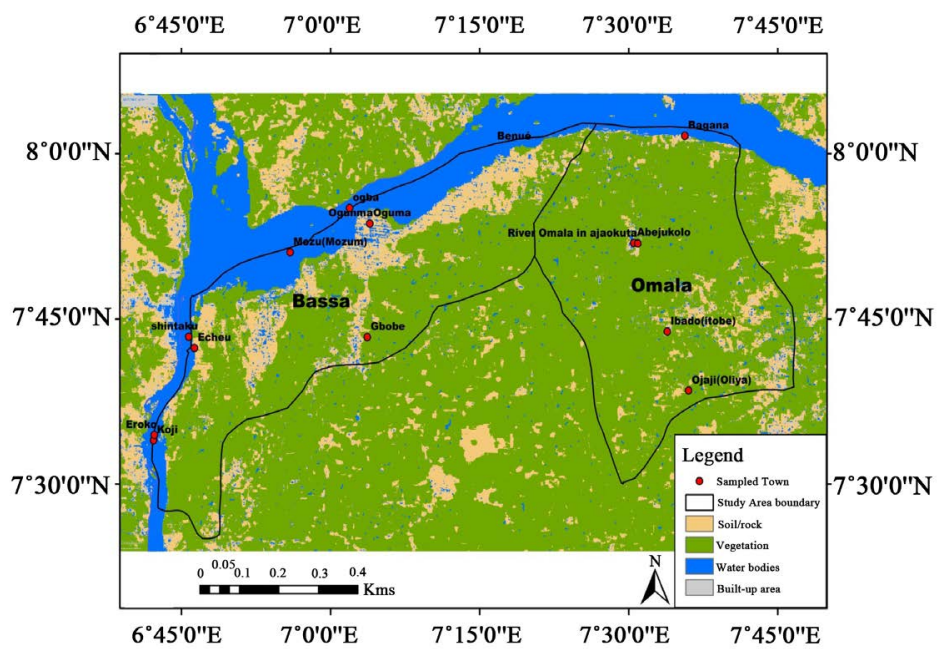

(b)



(c)

Figure 2. (a) Land-use/cover of 2010; (b) Land-use/cover of 2014; (c) Land-use/cover of 2018. 


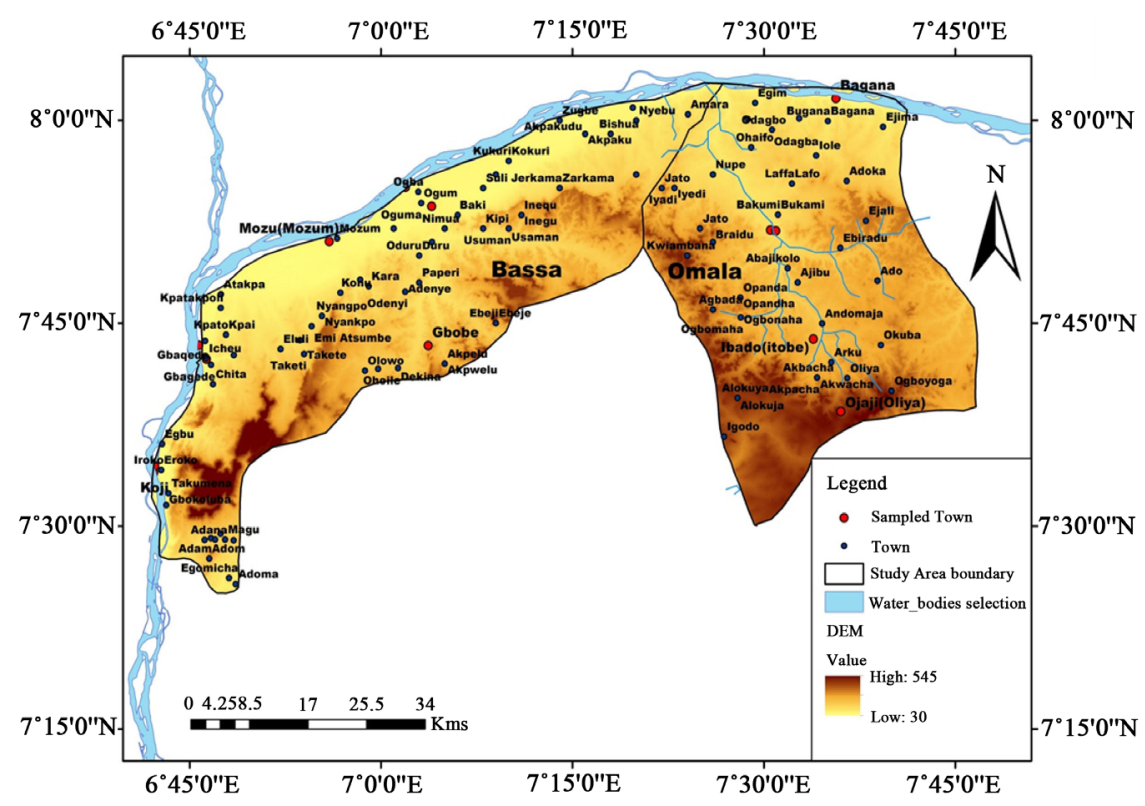

Figure 3. Elevation map of the study area.

Shintaku, Echeu, Eroko, Koji, Abejukolo, and Bagana and so are vulnerable to flooding. Therefore during preparation for flooding, people in the vulnerable communities can be evacuated and relocated to the communities in high elevated areas.

\subsection{Distance from River Channel}

Figure 4 presents the buffered map of the study area. This was performed to determine flood risk extent in accordance with proximity to river channel. It appears that areas, such as Oguma, Mozu, Bagana, Ogba, Icheu, Eroko, Koji and Akpaku, near the river network $(6 \mathrm{~km})$ are highly vulnerable to flood hazard. Areas such as Kofi, Kara, Odagba and Ohaife are at distance of 13 kilometres to the river, and are less vulnerable to flood hazard. The Southern region of the study area is not vulnerable to flood disaster by virtue of distance to the river Benue. They can be regarded as the safe zones where people can be advised to live or evacuation site during flooding in other to be safe from flood disaster. However, due to some active water channels such as river Omala in the southern eastern part, areas such as Abejukolo, Itobe, Ibado, Ajibu and it environment are vulnerable to flooding. Nevertheless, the effect of this parameter decreases in distances.

\section{Analysis of Socioeconomic Vulnerability}

\subsection{Children and Elderly Population}

Table 2 shows that children and elderly population constitutes $40.8 \%$ of the total population of the study area. The high percentage of the children and elderly population in the study area implies that the study area is highly vulnerable. This is as a result of increase in the burden of care following flooding and the ability 


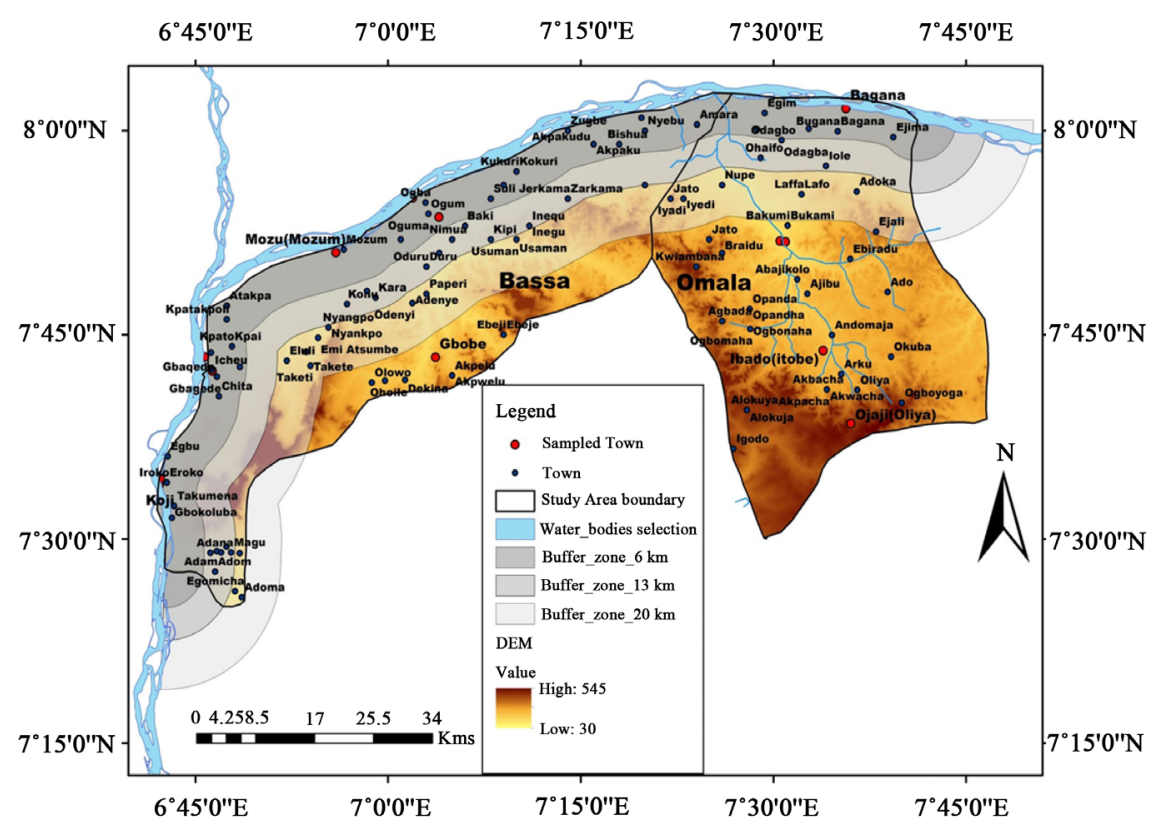

Figure 4. Buffer of river basin with base map.

Table 2. Age distribution of respondents.

\begin{tabular}{cc}
\hline Age Range (Years) & Respondents (\%) \\
\hline 0 to 14 & 25.1 \\
15 to 24 & 19.0 \\
25 to 59 & 40.2 \\
$>60$ & 15.7 \\
\hline
\end{tabular}

to mobilise them out of harm's way during flooding. The elderly population is characterised by a decline in functional ability which could inhibit their state of alertness, risk perception, and mobility. This can considerably increase their vulnerability therefore making them potential victims of any natural disaster including flooding.

\subsection{Gender}

Table 3 shows that female population constitutes 59.4\% of the total population of the study area shows the dominance over male population (40.6\%). This implies that the study area's population is vulnerable to flood disaster. Factors that increase the female vulnerability include restricted movement, lack of formal education due to religious and cultural believe, working of women in low wage informal sectors and earning lower wage than men, high household responsibilities of women which ranges from being a mother and care giver for both their children and the elderly. Moreover, until recently, most females in the study area commit their lives to household activities from an early age and have lesser opportunities to be involved in educational and social activities than males. This makes the female population highly vulnerable to natural hazards. 
Table 3. Gender distribution of respondents.

\begin{tabular}{cc}
\hline Gender & Respondents (\%) \\
\hline Male & 40.6 \\
Female & 59.4 \\
\hline
\end{tabular}

\subsection{Illiterate Population}

Table 4 shows that $52 \%$ of the population in the study area $(17.3 \%$ and $34.7 \%$ primary education and lack of formal education respectively) constitute the illiterate population. This implies that the study area is vulnerable to flood. Illiterate people lack understanding about hazard cause, trigger factors, severity and effects. They are also ignorant of how to prepare for emergency mostly depending on others to prepare and evacuate themselves during an imminent disaster. Moreover, the inability of an illiterate to read or write constitutes a significant difficulty for prompt action during emergency situation.

\subsection{Housing Type and Location}

Table 5 shows that $31 \%$ and $9.3 \%$ of houses in the study area were constructed with mud and Mud/wooden frame respectively while $63.5 \%$ of the houses were located in risk areas. The quality of the Cement and mud houses found in the study area are substandard, while wooden houses are inferior and therefore at risk of severe damage during flood. Generally, residents in the study area lack maintenance and renovation culture even as substandard buildings have an extremely high density in flood plain areas. The damage caused by natural hazards is likely to be enormous in the study area as a result of great vulnerability exhibit by buildings located in close proximity to water bodies and substandard houses built on flood plains. The results presented on Table 5 showed that housing quality were not only poor but mostly situated in high flood risk areas. The great numbers of human lives and properties that reside in such poorly constructed buildings and risk areas are at great risk of flood hazard. The infrastructure and poorly constructed houses in the low-lying places and flood plains of the study area will be easily flooded and damaged during flooding. These factors could turn the natural hazard into a disaster.

\subsection{Poverty}

Table 6 and Table 7 show that, 57\% constitute population of low income group, $41.6 \%$ constitute the population of the middle income group while only $1.3 \%$ of the population constitute the high income group. Unemployed members and the student population the study area constitute $34.5 \%$ and $28.2 \%$ respectively, while others (37.3\%) are unemployed. Natural disasters impact more on the poor population because of their lack of resources to build or rebuild their homes and also meet other critical needs during a disaster cycle. This makes them unable to make adequate preparation for flood hazard thereby reducing their resistance and 
Table 4. Distribution of literacy rate.

\begin{tabular}{cc}
\hline Literacy Rate & Respondents (\%) \\
\hline No Formal Education & 34.7 \\
Primary & 17.3 \\
Secondary & 13.8 \\
Post-Secondary & 34.7 \\
\hline
\end{tabular}

Table 5. Housing types distribution.

\begin{tabular}{cccc}
\hline House Type & Respondents (\%) & Location & Respondents (\%) \\
\hline Cement & 37.9 & Highland & 36.5 \\
Mud & 31 & Floodplains & 21.4 \\
Cement/Mud & 20.1 & Close to canal & 18.1 \\
Wood/Mud & 9.3 & Close River channel & 23.9 \\
Others & 1.6 & & \\
\hline
\end{tabular}

Table 6. Income range distribution.

\begin{tabular}{ccc}
\hline Income Class & Income Range (Naira) & Respondents (\%) \\
\hline Very low & $<13,000$ & 24.5 \\
Low & 13,000 to 45,000 & 32.5 \\
Middle & 45,000 to 100,000 & 41.6 \\
High & $>100,000$ & 1.3 \\
\hline
\end{tabular}

Table 7. Employment status distribution.

\begin{tabular}{cc}
\hline Employment Status & Respondents (\%) \\
\hline Employed & 34.5 \\
Unemployed & 37.3 \\
Students & 28.2 \\
\hline
\end{tabular}

coping capacity to flood hazard. This result shows that majority of the population in the study area are linked with poverty thereby making them more vulnerable to flood disaster.

\subsection{Assessment of Flood Early Warning System (EWS)}

Table 8 presents the assessment of flood forecasting, communication gadgets and alert dissemination of respondents in the study area. Analysis shows that majority (29.9\%) of the households in the study area do not have access to any weather information, $36.5 \%$ access weather information through audio vision (radio and television), $17.9 \%$ access weather information through traditional methods while $25 \%$ rely on local authority for weather information. 
Table 8. Flood forecasting, communication gadgets and alert dissemination.

\begin{tabular}{|c|c|c|c|c|c|}
\hline $\begin{array}{l}\text { Medium } \\
\text { of EWS }\end{array}$ & $\begin{array}{c}\text { Respondents } \\
(\%)\end{array}$ & $\begin{array}{l}\text { Accessible } \\
\text { Weather } \\
\text { Elements }\end{array}$ & $\begin{array}{c}\text { Respondents } \\
(\%)\end{array}$ & $\begin{array}{c}\text { Forecast } \\
\text { Frequency }\end{array}$ & $\begin{array}{c}\text { Respondents } \\
(\%)\end{array}$ \\
\hline Television & 15.1 & Temperature & 32.1 & Daily & 11.8 \\
\hline Radio & 21.4 & Precipitation & 30.8 & Weekly & 9.1 \\
\hline Newspaper & 0 & $\begin{array}{l}\text { Relative } \\
\text { Humidity }\end{array}$ & 3.6 & Monthly & 2.7 \\
\hline Internet & 0.5 & Pressure & 1.6 & Occasionally & 50.5 \\
\hline $\begin{array}{c}\text { Local } \\
\text { Authority }\end{array}$ & 25 & Cloud Cover & 1.9 & Non & 25.8 \\
\hline $\begin{array}{l}\text { Traditional } \\
\text { Method }\end{array}$ & 17.9 & Non & 29.9 & & \\
\hline Telephone & 0.5 & & & & \\
\hline No Medium & 19.5 & & & & \\
\hline
\end{tabular}

Analysis shows that majority $(62.9 \%)$ of the households that have access to weather information can only access temperature and precipitation while majority (50.5\%) of the respondents only access weather information occasionally. This shows the high rate of vulnerability as a result of inadequate early warning systems in the study area.

The residents of the study area have faith in the use of indigenous method for forecasting flood year. However this method will not be able to forecast flood caused by dam release or failure. This has been the cause of flooding in the study area over the years.

\section{Flood Hazard Map}

Figure 5 shows that, aside communities such as Mozu, Ogba, Bagana, Icheu, etc, with close proximity to the River Benue, Other communities such as Gbobe and Abejukolo are highly susceptible to floods. This is as a result of local River channels (River Omala) whose source is the river Benue flowing downstream toward Abejukolo and the surrounding areas. Other communities such as Ibado, Nupe, Taperi, Inyanpo, etc. has Medium to low flood risk. However, when there is huge discharge of water from upstream dams and the river exceeds it bank at full stage for days, the low and medium susceptible areas will become highly susceptible to flood.

The flood hazard map also provide existing risk information for land use planning and accurate development plans for new and existing urban areas such as Oguma and Abejukolo communities. Oguma and Abejukolo are major urban areas in the study area and are highly susceptible to flood. The hazard map will enable developers and engineers to perform satisfactory evaluation of costs of flood damages and flood reduction benefits. 


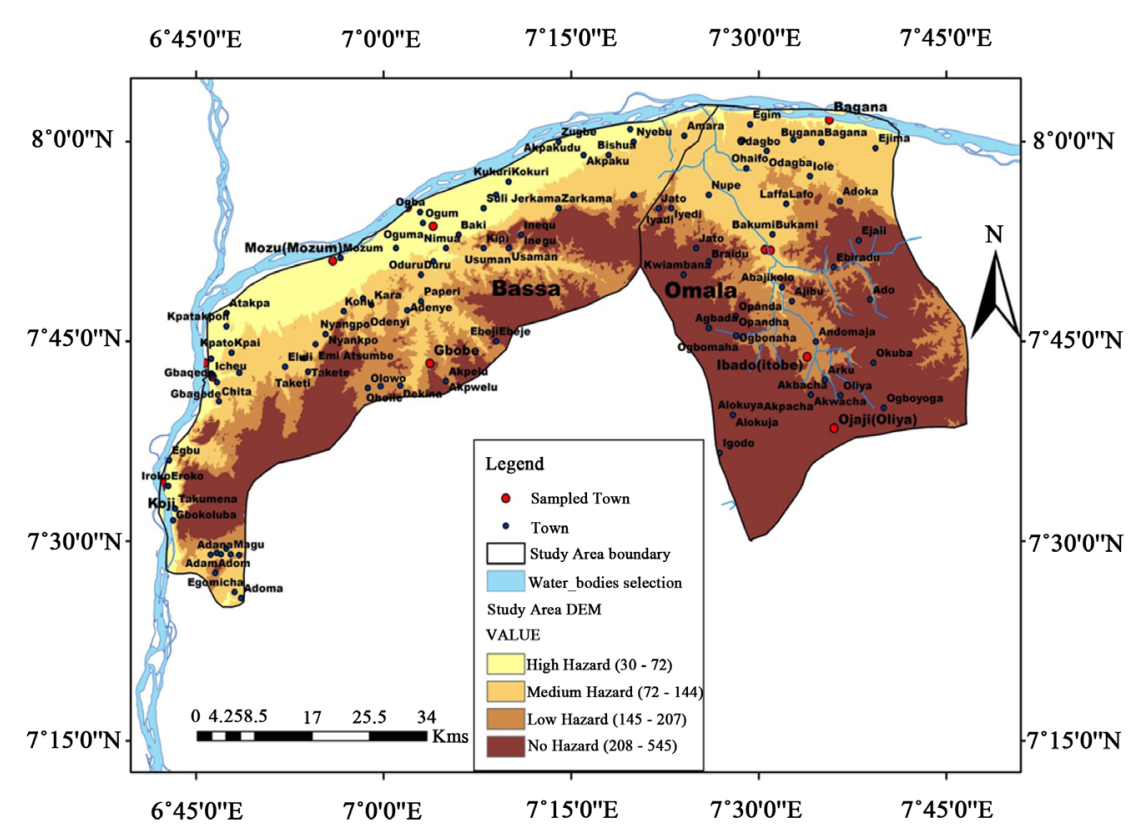

Figure 5. Flood hazard map of the study area.

\section{Conclusion}

The study has investigated flood risk and assesses vulnerability to flood along the River Benue Basin of Kogi state using geospatial techniques and survey. The study delineated the areas at flood risk, classified the vulnerable areas and pointed out the socio-economic factors which increase the population vulnerability in the river Benue basin of Kogi State. Many lives and property are liable to be damaged by flood as long as people continue to live in these areas prone to flood. The analysis shows that many communities settled too close to the river banks. In some cases, it seems the communities (Mozu and Bagana) are even on the river pathway. The influence of poverty on disaster cannot be overemphasised. To effectively manage risk and reduce vulnerability, economic safety nets and jobs opportunities should be created. This will eradicate poverty to a minimum level which in turn will help achieve the goal of disaster risk reduction. This study advocates the need for paradigm shift from the Nigeria conventional post disaster phases of flood disaster management which include response and resettlement to also include pre disaster phases of prevention and preparedness. A workable, proactive and people centred policy and plan together with results from this effort will greatly lower the vulnerability to flooding and provide an authentic control and dependable management.

\section{Recommendations}

Public awareness and education should be made in understandable languages by all relevant disaster management stakeholders in collaboration with the traditional institutions and faith based organisations in the communities on the dangers associated with constructing buildings on areas prone to flood and other practices that can alter the environment and originate risk to individuals. 
There is need for constant flood stage monitoring and continual vulnerability mapping by the relevant agencies especially during the months of April to October when there is high probability of flooding.

Government must develop guidelines for land use in the river basins and ensure full observance of development protocols for the study area as regards the encroachment of flood plains particularly at Bagana, Eroko, Abejukolo, Oguma, Mozu and Icheu.

All the communities that are located at the banks and within the buffer distance of $6 \mathrm{~km}$ of River Benue and its major tributaries and which are prone to floods should be urgently relocated while enacting legislation that would ban new development in floodplains of the major towns such as Bagana, Mozu and Ogba.

NEMA should collaborate with the Local Government Council and the traditional rulers of the various communities on the Benue basin to provide flood warning systems and effective flood risk communication to the inhabitants.

\section{Conflicts of Interest}

The authors declare no conflicts of interest regarding the publication of this paper.

\section{References}

[1] National Oceanic and Atmospheric Administration (NOAA) Coastal Services Centre, Risk and Vulnerability Assessment Steps (1998) Environmental Analysis Risk and Vulnerability Assessment Tool (RVAT).

[2] DMSG-Disaster Management Support Group (2001) The Use of Earth Observing Satellites for Hazard Support Group. Final Report, NOAA, Department of Commerce, USA.

[3] Ologunorisa, T.E. (2004) An Assessment of Flood Vulnerability Zones in the Niger Delta, Nigeria. International Journal of Environmental Studies, 61, 31-38. https://doi.org/10.1080/0020723032000130061

[4] Nigeria Hydrological Services Agency (NHSA) (2016) National Flood Outlook for 2016. http://www.nihydro.gov.ng

[5] Jayasselan, A.T. (2006) Drought and Floods Assessment and Monitoring Using Remote Sensing and GIS [Electronic Version]. Satellite Remote Sensing and GIS Application in Agricultural Meteorology, 2006, 291-313.

[6] Ishaya, S., Ifatimehin, O.O. and Abaje, I.B. (2009) Mapping Flood Vulnerable Areas in a Developing Nigeria. Journal of Sustainable Development in Africa, 11, 180-194.

[7] Irimescu, A., Craciunescu, V., Stancalie, G. and Nertan, A.T. (2010) Remote Sensing and GIS Techniques for Flood Monitoring and Damage Assessment Study Case in Romania. 4th International Scientific Conference BALWOIS, Ohrid, 25, 29 May 2010, 1-10.

[8] Clement, A.R. (2012) Causes of Seasonal Flooding in Flood Plains: A Case of Makurdi, Northern Nigeria. International Journal of Environmental Studies, 69, 904-912. https://doi.org/10.1080/00207233.2012.730668 